NBER WORKING PAPER SERIES

WHY SOME DOUBLE TAXATION MIGHT MAKE SENSE: THE SPECIAL CASE OF INTER-CORPORATE DIVIDENDS

\author{
Randall Morck \\ Working Paper 9651 \\ http://www.nber.org/papers/w9651 \\ NATIONAL BUREAU OF ECONOMIC RESEARCH \\ 1050 Massachusetts Avenue \\ Cambridge, MA 02138 \\ April 2003
}

Comments by Lucien Bebchuk, Martin Feldstein, Assaf Razin, Emmanuel Saed, Andrei Shleifer, Rene Stulz, and Bernard Yeung are gratefully acknowledged. Work by Gloria Tian for constructing diagrams of Canadian corporate ownership is much appreciated. The views expressed herein are those of the authors and not necessarily those of the National Bureau of Economic Research.

C2003 by Randall Morck. All rights reserved. Short sections of text not to exceed two paragraphs, may be quoted without explicit permission provided that full credit including Cnotice, is given to the source. 
Why Some Double Taxation Might Make Sense: The Special Case of Inter-corporate Dividends Randall Morck

NBER Working Paper No. 9651

April 2003

JEL No. G3

\begin{abstract}
Arguments for eliminating the double taxation of dividends apply only to dividends paid by corporations to individuals. The double (and multiple) taxation of dividends paid by one firm to another - intercorporate dividends - was explicitly included in the 1930s to eliminate pyramidal corporate groups. These structures exist elsewhere, and are associated with corporate governance problems, corporate tax avoidance, and a greater concentration of economic power than is currently possible in the United States. Current US tax reform proposals do not distinguish dividends paid to individuals from intercorporate dividends and, by eliminating double taxation on both sorts of dividends, may allow pyramidal groups in the US again for the first time since the 1930s.
\end{abstract}

Randall Morck

Faculty of Business

University of Alberta

Edmonton, Canada T6G 2R6

and NBER

randall.morck@ualberta.ca 


\title{
Why Some Double Taxation Might Make Sense: The Special Case of Inter-corporate Dividends
}

\author{
Randall Morck
}

\section{Introduction}

The double taxation of intercorporate dividends was introduced in the 1930s to render economically unviable certain corporate structures which were believed to facilitate governance problems, tax avoidance, and highly concentrated corporate control

The structures in question are corporate groups, clusters of seemingly separate firms connected by complicated networks of intercorporate equity ownership. The most common of these structures is the pyramidal corporate group, in which a wealthy family or individual typically controls a family firm, which controls majority voting blocks in several other firms, with public shareholders holding the remaining shares. Each of these firms, in turn, holds majority voting blocks of more companies, again with public investors holding the remaining shares. Each of these controls yet more firms, and so on ad valorem. Such structures can encompass hundreds of nominally separate publicly traded and private firms, and can be more than a dozen layers deep. Pyramidal corporate groups allow wealthy individuals or families to control corporate assets worth vastly more than their actual wealth. They are the structures that permit a tiny elite to control the greater parts of the corporate sectors in many countries.

Pyramidal groups may serve useful purposes in countries with malfunctioning markets. Group member firms can transact business with each other while avoiding the dysfunctional institutions of countries in early stages of economic development. However, the social welfare value of pyramidal groups in developed economies is uncertain at best. 
This is because pyramid group member firms have been shown to shift assets and income among themselves, much as do the subsidiaries of multinational firms. This income shifting has two probable objectives. First, pyramid group companies can use such intercorporate income shifting techniques, such as the manipulation of transfer price, to enhance their income tax avoidance efforts. The economic importance of this sort of income shifting in countries with extensive pyramidal groups is little studied, though Congress apparently felt it to be a major problem in the 1930s. Second, pyramid group firms can use such intercorporate income shifting to transfer income and assets away from firms whose cash flows largely accrue to public investors and into firms whose cash flow largely accrue to a controlling shareholder. Substantial empirical evidence now supports the economic importance of this sort of income shifting in countries with extensive pyramidal groups.

Pyramidal corporate groups also allow highly concentrated corporate control. The shareholder who controls the apex firm in the pyramid indirectly controls all the other firms in the pyramid. These can collectively be worth vastly more than her personal fortune. This feature of pyramidal groups lets a handful of families control the greater part of the corporate sectors of many developing countries.

Dividends from firms low in such pyramidal structures must be relayed through a chain of to the controlling shareholder. If dividend taxes accrue at the corporate level each time the dividend is passed from one firm to the next, as US "double taxation" of dividends currently mandates, such pyramidal structures are prohibitively expensive. However, pyramidal business group structures can be assembled readily in countries that tax dividend income only once.

An explicit purpose of President Roosevelt's 1933 and 1934 tax reforms was the extension of double taxation to intercorporate dividends to force the dismantling of pyramidal groups. The 
reforms were successful, for such structures are currently unknown in the United States. However, with the passage of time, the economic rational underlying this particular aspect of dividend double taxation has also been forgotten.

Other regulatory and legal constraints, such as the Public Utilities Holding Company Act, might limit income shifting by pyramidal groups in the United States, should they reappear after the elimination of all double taxation of dividend income. Additional diligence by tax authorities and alertness by corporate governance watchdogs might well serve. However, both the efficacy of these constraints and the potential costs of such added diligence to taxpayers and investors are difficult to predict.

Strong economic arguments suggest abolishing the double taxation of dividends paid to individuals. However, these arguments have no application whatsoever to dividends paid by one corporation to another. Nonetheless, the current tax reform proposal fails to distinguish dividends paid to individuals from dividends paid by one firm to another.

The purpose of this paper is to highlight this distinction. The original intent of Congress and the White House in applying double taxation to intercorporate dividends may well remain economically important, despite the validity of current arguments against double taxation of dividends paid to individuals. Appreciating this distinction may allow nuanced reforms that eliminate the problems of the current US dividend double taxation without recreating the problems that led to the reforms of the 1930s.

If the elimination of all dividend double taxation is enacted, and pyramidal groups form again in the United States for the first time since the 1930s, economists will have a fascinating new phenomenon to study. Moreover, the potentially deleterious social welfare consequences of such a resurgence suggest an urgent need for additional study of this long-forgotten (in the U.S.) 
phenomenon.

The structure of the paper is as follows. Section 2 describes pyramidal corporate groups, the structures of corporate ownership typical in most countries. Section 3 explains how the US tax code, by subjecting intercorporate dividends to double taxation, renders such groups unviable. Section 4 describes how the US tax reforms of the 1930s introduced double taxation of intercorporate dividends explicitly to undermine pyramidal groups, which until then had been important in that country. Section 5 reviews the current literature on pyramidal corporate groups outside the United States and assesses corporate governance, tax avoidance, and political economy implications of these structures. Section 6 reviews arguments regarding the elimination of double dividend taxation, and shows how these arguments apply only to dividends paid by firms to individuals, and have no relevance to intercorporate dividends. Section 7 concludes.

\section{Examples of Pyramidal Corporate Groups}

Figure 1 illustrates a stylized pyramidal corporate group. A family firm owns $51 \%$ of firm A, which owns $51 \%$ of Firm B, which owns $51 \%$ or firm $\mathrm{C}$, and so on. In practice, the situation is usually more complicated, with non-voting and multiple-voting shares, golden shares, crossholdings, and other additional ornaments. Figure 2 illustrates a part of an actual Canadian pyramidal corporate group, the Hees-Edper Group. The full group cannot be graphed here, as it is sixteen layers high and contains several hundred firms. This group is unusually large, but its structure is typical of the pyramidal corporate groups that dominate the economies of most countries.

It is possible to represent all the firms in smaller groups in other countries in a single diagram. Thus, Figure 3 sketches the structure of the Anglo-American Group of South Africa as it 
appeared in the mid 1990s. The group consists of a mixture of publicly traded controlled corporations and private corporations, and deviates from a simple pyramidal structure in that many controlled corporations own blocks of stock in the companies that control them, indirectly or directly. Figure 4 sketches the Italian companies controlled by the Agnelli family via a pyramidal group structure, and Figure 5 sketches the firms in the Deutsche Bank's pyramidal group in Germany. These structures are simpler than Anglo-American, and closer to the archetypal pyramidal form of Figure 1 and Figure2.

Note that, while the statistical evidence discussed below associates pyramidal corporate groups with potential tax avoidance, corporate governance, and concentrated control problems, some pyramidal groups show no evidence of such problems at all. For example, Daniels et al. (1995) find no evidence whatsoever of poor corporate governance or any other problems in the Hees-Edper pyramidal group. There is also no evidence of any problems in the Anglo-American Group, Agnelli Group, or Deutsche Bank Group. These structures are displayed only to illustrate the general nature of pyramidal groups, in order to set the stage for considering possible problems in other similarly structured groups.

While La Porta et al. (1999) show pyramidal corporate groups are the most common ownership structure in most countries, they are not the only corporate group. For example, large Japanese corporations are organized into keiretsu, corporate groups in which each member firm owns a small equity stake in every other member firm. Although each individual intercorporate equity stake is tiny, a majority of the stock in each keiretsu firm is held collectively by all the other firms in its group. Morck and Nakamura (1999) discuss the historical transformation of family controlled pyramids into keiretsu in Japan, and show how keiretsu engender corporate governance problems. 
In contrast to all of the above structures, Figure 6 illustrates the much simpler structure typical of the domestic operations of most large US corporations. The Minnesota based company 3M, formerly Minnesota Mining and Manufacturing Corporation, is more than $99 \%$ owned by public shareholders, including individuals and investment funds. As of its most recent SEC proxy filing, corporate insiders own about 1.5 million of 3M's approximately 390 million outstanding shares $-\mathrm{a}$ combined stake of less than one percent. The firm's largest shareholder is State Street, an investment management firm, which holds about 30 million shares, roughly $7.7 \%$. The firm has no publicly traded domestic subsidiaries. While Holderness et al. (1999) and others show that moderately large shareholders have been and remain important in many U.S. firms; the widely dispersed ownership structure of $3 \mathrm{M}$ is quite typical of the largest US firms. And multiple layers of intercorporate ownership encompassing large numbers of publicly traded firms, such as those shown in Figures 2 through 5, are essentially unknown in the US. ${ }^{1}$

La Porta et al. (1999) show such that most large corporations in most countries are members of pyramidal groups. Indeed, the United States (and United Kingdom) are highly unusual in that their large corporations are mostly freestanding independent entities.

\section{How Double Taxation of Intercorporate Dividends Crumbles Pyramids}

The United States subjects dividends to 'double taxation', in the sense that 'dividends received' are taxable income for recipients and 'dividends paid' are part of taxable income for the payer. Where the dividends are paid by corporations to individuals, this has the effect of raising the

\footnotetext{
${ }^{1}$ The only U.S. exception I have discovered is a Massachusetts venture capital firm called Thermo Electron, which retains stakes in publicly traded high tech firms as an intermediate step to spinning them off. This results in a two-tiered pyramid, which is still much simpler than the structures typical in other countries. I am grateful to Martin Feldstein for bringing Thermo Electron to my attention.
} 
true rate of taxation on dividends, which combines the rates paid by the recipient and the payer. This effect has received considerable attention, which is summarized in section 6 .

However, a second and lesser known aspect of US double dividend taxation is that it also subjects dividends paid by one firm to another to double taxation - though at lower rates. This taxation of intercorporate dividends makes pyramidal corporate groups financially unviable.

To see this, compare the details of US tax law and the tax law of Canada, which does not subject intercorporate dividends to double taxation. Table 1 shows that both countries tax dividends when they are initially paid out by a company and when they are received by individuals. The Canadian tax rate on dividend income, $31.34 \%$, is lower than the tax rate on general income, $46.41 \%$. This reflects a partial credit for taxes already paid by the corporation that initiated the dividend.

Where the tax codes of the two countries differ starkly is in their treatment of dividends paid by one corporation to another. Although the United States tax rate on dividend income received by corporations is substantially lower than that on dividend income received by individuals, it is positive unless the intercorporate stake is $80 \%$ ownership or higher. In contrast, Canadian intercorporate dividends are entirely tax-exempt if the intercorporate stake is $10 \%$ or more. When a corporation receives a dividend from another corporation, in which it owns a common equity stake of $10 \%$ or more, the Canadian tax authorities regards this as an internal transfer of funds in a corporate group, not as taxable income paid by one legal person to another. ${ }^{2}$

To see the importance of this difference, return to Figure 1. If the pyramidal group depicted

\footnotetext{
${ }^{2}$ There are two main exceptions to this rule. The first is a complex set of rules for preferred shares and the second declares dividends paid to corporate investors that do not exercise control (stake $<10 \%$ ) to be taxable income for those investors.
} 
in that figure were in the US, a dividend paid by firm F would be subject to a $35 \%$ tax as part of that firm's taxable income. As the dividend passed up through the pyramid, it would be subject to a seven per cent tax at each level. Finally, the controlling shareholder of the apex firm would pay a $38.6 \%$ personal income tax on dividends received. Consequently, the effective tax rate on dividends the family receives from the firms in level $\mathrm{F}$ of its pyramid is $1-\left[(1-0.35) \times(1-.07)^{5} \times(1-.386)\right]$ $=72.2 \%$. The more layers in the pyramid, the higher is the effective tax on the controlling shareholder's final dividend income. If the dividend had been paid directly to an individual, the tax rate would have been $1-[(1-0.35) \times(1-.386)]=60.1 \%$. The penalty for the pyramidal structure is an extra $12.1 \%$ added to the marginal tax rate on dividends received by the controlling shareholder. In essence, double taxation becomes 'multiple taxation', with the dividend subjected to taxation as it passes through each link in the chain of companies from firm $\mathrm{F}$ to the controlling shareholder.

In contrast, the same pyramid in Canada would subject the same dividend only to a corporate income tax of $38.62 \%$ when paid out by Firm F and a $31.34 \%$ personal income tax when received by the controlling shareholder. ${ }^{3} \quad$ The combined rate is $1-[(1-0.3862) \times(1-0.3134)]=57.86 \%$. This combined rate does not depend on how many layers the pyramid contains. There is no tax penalty to the controlling shareholder in Canada for funneling the dividend through a long sequence of corporations, and multilayered pyramidal corporate groups are consequently commonplace in that country.

Table 2 lists effective intercorporate dividend tax rates for 1997, along with a characterization of the ownership structure of large firms in each country. The ownership structure

3 The precise rates depend on the province. Those shown are for Ontario. Rates are substantially lower in Alberta and higher in Québec and the Atlantic provinces. 
characterization variable is constructed as follows: For each country, the names of the top ten businesses are obtained. The ownership structures of these businesses, beginning with the largest, are tracked back through holding companies and other intermediate owners to the ultimate owners, as in La Porta et al. (1999). As soon as one pyramidal structure is found, 'yes' is entered. Pyramidal structures include those controlled by wealthy families, individuals, governments, and widely held firms. In addition, if intercorporate cross holdings of the sort described above in connection with Japanese keiretsu are found, 'yes' is also entered. If none of these structures are found in connection with any top ten firm in the country, 'no' is entered. ${ }^{4}$

Table 2 shows that of the 33 countries for which data are available, only the United States levies a tax on intercorporate dividends. (India and Korea have statutory taxes on intercorporate dividends, but exempt firms on special lists. These lists include all the firms in major established pyramidal groups. These taxes may, however, deter the rise of new rival groups.) It also shows corporate groups, pyramidal or otherwise, controlling top firms in every country except the United States and the United Kingdom. The pattern in Table 2 is consistent with intercorporate dividend taxation in the United States rendering pyramidal and other corporate groups economically infeasible.

The absence of corporate groups in the United Kingdom is perhaps a vestige of intercorporate dividend taxation, which apparently prevailed in that country until 1973 - see King (1977). However, Aganin and Volpin (1998) show that Italy also abolished the double taxation of intercorporate dividends in 1977 and subsequently saw an increased use of pyramidal corporate groups. A cross section of intercorporate dividend tax rates for 1983, the first year for which data comparable to those in Table 2 are available, reveals Belgium, France, Greece, and Portugal also

\footnotetext{
${ }^{4}$ La Porta et al. (1999) kindly made their raw data available to us as a starting point for this exercise.
} 
taxing intercorporate dividends.5 These countries subsequently ceased taxing intercorporate dividend income, and currently have pyramidal corporate groups.

Why pyramidal groups failed to resurge in the United Kingdom when double taxation of intercorporate dividends ended, but rebounded in other countries that effected similar tax reforms is puzzling. LaPorta et al. (1999) propose that strong investor protection may limit controlling shareholders' ability to extract private benefits. The substantial legal rights British shareholders enjoy might thus serve to render such groups less useful to rapacious insiders there than in Italy and other countries with weaker investor protection. However, pyramids resurged in Italy after the 1977 despite a simultaneous tightening of securities rules. Another possibility is that vigorous enforcement of the tax code in the UK prevents controlling shareholders from tunneling, and thus, again, limits their ability to extract private benefits of control. This is consistent with Dyck and Zinglales (2001) and Nenova (2000), who report relatively small private benefits of control in the United Kingdom. However, other countries with strong investor protection rules and wellfunctioning legal and tax collection systems, including Australia and Canada, have extensive pyramidal corporate groups. It may be that other features of the United Kingdom's legal and regulatory system deter pyramidal groups in ways not currently understood.

Further work on the relationship between intercorporate dividend taxation and the viability of pyramidal groups in different countries at different points in time is clearly needed to inform current tax reform discussion in the US.

\section{The History of Intercorporate Dividend Taxation in the United States}

Pyramidal corporate groups were commonplace in the United States in the 1920s. The

5 Though these countries may have exempted large established corporate groups. 
largest US pyramids, which were built around power companies, encompassed hundreds of firms and were as many as ten layers high. ${ }^{6}$ In 1928, the Federal Trade Commission issued a report on abusive practices of pyramids. Noting widespread instances of tunneling, poor governance, and monopolistic practices, the report stated that pyramidal groups were "frequently a menace to the investor or the consumer or both." ${ }^{7}$ Following the 1929 market crash, many of these pyramidal groups defaulted on their debts. ${ }^{8}$

Intercorporate dividends taxation was introduced in the United States in 1935 with the explicit objective of breaking up pyramidal groups. Blakey and Blakey (1935) summarize the Roosevelt tax reform of 1935 , which proposed intercorporate dividend taxes at $15 \%$ of the normal dividend tax rate as a measure to "prevent the evasion through affiliates" of the corporate income tax. They note that "the tax would vary from $1 \frac{1}{2}$ per cent to $2^{5} / 8$ per cent" for an individual company, but that "[i]n the case of pyramided complex holding companies, such taxes might amount to 8 or 10 per cent."

Robert Jackson, Assistant General Counsel to the Treasury Department, presenting the reforms to the Senate Finance Committee, "stressed the secondary effects of such taxes on dividends in discouraging undesirable practices of holding companies" (pyramidal groups), and discussed some such problems in detail:

"The tax problems arising out of systems of holding companies, subholding companies, operating companies, and mixed companies, are very serious. For example, one such system as of December 31, 1933, contained approximately 270 companies of which 128 were public utility operating companies located in several and widely separated states, and at least 31 of which would be classed as subholding companies. The corporation filed consolidated returns showing no tax due in any of the years 1929 through 1933. The system was not so modest about its profits in its reports to stockholders, and the Bureau began the task of audit. The auditing to date has required the services of 108 field agents for an aggregate period of

6 Abel (1999).

7 FTC, Utility Corporation, Senate Document No. 92, 70th Congress, 1st session. (1928).

8 Philips (1993) p. 239. 
11,488 days, the service of 16 auditors for a period of 2,640 days, as well as the services of the supervising staff. The task is not yet nearing satisfactory completion. The investigation is complicated by the great volume of security transactions among the different companies of the group. In some instances securities were transferred through as many as 10 intermediary companies on the way from starting point to destination. A dollar of earnings would likewise run through several companies before reaching a resting place.

"Some of these holding companies have imposed charges upon underlying operating utilities for the income-tax liability which the operating companies would have paid if they had filed a separate return. Then by eliminating the profit through the consolidated return, no tax was paid to the government. The holding company had collected the tax and kept it for itself. One company collected from its subsidiaries between 1926 and 1929 in excess of one and one-half million dollars on this basis. This particular device is probably now defeated by withdrawing the privilege of filing consolidated returns.

"Elimination of consolidated income-tax returns does not eliminate the necessity for auditing these gigantic systems, nor does it make the problem less difficult. Managements that are so disposed still find it possible to shift security transactions from one company to another for the purpose of allocating losses or profits so as to avoid taxes, and can still control and divert earnings from one to another unit in the form of service charges, accountancy tax consultant, and management fees, and by various other changes can so reduce taxable income of some units and increase net income of others that they can accomplish many of the results of consolidated returns.

"It is almost impossible, with systems of this magnitude and complexity, to determine the tax status of many companies. And, after an audit is made, the situation is easily and rapidly changed, to avoid its results.

"In 1929, a certain corporation recorded on its books a capital gain in security transactions of $\$ 18,000,000$ which was eliminated through a consolidated return. The Bureau found, however, that there was no lawful basis for the consolidated return, and the resulting tax was about $\$ 2,000,000$. However, it was then discovered that a letter, written in 1933, purported to confirm what was claimed to have been an oral agreement made in 1929, although it had for years been left unwritten. By its terms the two companies declared their transactions to be continuing and not to be finally fixed and determined until all taxes were finally paid. The object of the device was apparently to prevent the closing of the transactions in 1929 and to throw the profit in whatever year was found to be convenient."

The House initially rejected the idea of taxing intercorporate dividends at $15 \%$ of the regular rate, and the 1935 Act contained a compromise rate of 10\%. Blakey and Blakey (1936) record that the $15 \%$ figure was implemented in 1936.

Blakey and Blakey (1935) sum up the Roosevelt administration's taxation objectives thus:

\footnotetext{
${ }^{9}$ Senate Finance Committee Hearings, pp. 223-224.
} 
"There can be no denying that the President's message was an attack upon wealth; he and his followers would say, not upon innocent wealth, but upon concentrated, monopolistic, taxevading, unsocial wealth, and particularly upon that taken from the masses by the vicious, pyramided, consciousless holding companies."

That this accurately reflected the view from the White House is also clear. Roosevelt (1942)

writes in the America Economic Review,

"Tax policies should be devised to give affirmative encouragement to competitive enterprise. Attention might be directed to increasing the intercorporate dividend tax to discourage holding companies ...".

Roosevelt (1942) clarifies his views:

"Close financial control, through interlocking spheres of influence over channels of investment, and through the use of financial devices like holding companies and strategic minority interests, creates close control of the business policies of enterprises which masquerade as independent units.

"That heavy hand of integrated financial and management control lies upon large and strategic areas of American industry. The small-business man is unfortunately being driven into a less and less independent position in American life. You and I must admit that.

"Private enterprise is ceasing to be free enterprise and is becoming a cluster of private collectivisms; masking itself as a system of free enterprise after the American model, it is in fact becoming a concealed cartel system after the European model.

"We all want efficient industrial growth and the advantages of mass production. No one suggests that we return to the hand loom or hand forge. A series of processes involved in turning out a given manufactured product may well require one or more huge massproduction plants. Modern efficiency may call for this. But modern efficient mass production is not furthered by a central control which destroys competition between industrial plants each capable of efficient mass production while operating as separate units. Industrial efficiency does not have to mean industrial empire building.

"And industrial empire building, unfortunately, has evolved into banker control of industry. We oppose that.

"Such control does not offer safety for the investing public. Investment judgment requires the disinterested appraisal of other people's management. It becomes blurred and distorted if it is combined with the conflicting duty of controlling the management it is supposed to judge.

"Interlocking financial controls have taken from American business much of its traditional virility, independence, adaptability, and daring-without compensating advantages. They have not given the stability they promised.

"Business enterprise needs new vitality and the flexibility that comes from the diversified efforts, independent judgments and vibrant energies of thousands upon thousands of independent businessmen.

"The individual must be encouraged to exercise his own judgment and to venture his own small savings, not in stock gambling but in new enterprise investment. Men will dare to compete against men but not against giants." 
Blakey and Blakey (1935) concede that the diverting of taxation from the primary purpose of raising revenue to other major purposes involves great hazards." However, they justify the Roosevelt tax reforms, noting that

"Statesmanship requires that the Ship of State shall not be allowed to rot in a stagnant Sargasso Sea nor be rent asunder by explosions of dynamite in its hold nor be dashed upon the rocks by the tidal waves of radically revolutionary storms and earthquakes."

In summary, although the tax reforms of the 1930s were unquestionably populist measures aimed at big business, the attack not without deliberation. A purpose of these reforms was to subject dividends passed through layers of firms in pyramidal groups to multiple taxation, and thereby render such groups unviable. As the writing style in the American Economic Review deteriorated over the decades, so has this purposes been forgotten.

\section{Why Pyramidal Corporate Groups Are Probably Still Undesirable}

This section outlines three economic reasons why pyramidal corporate groups might be undesirable. First, pyramidal groups are statistically associated with corporate governance problems in many countries. Second, pyramidal groups create scope for tax avoidance strategies by corporations. Third, pyramidal groups allow highly concentrated corporate control. Each is now examined in turn.

\section{Pyramids and Corporate Governance}

This section explains the two central agency problems that contribute to poor corporate 
governance in many US firms, and how an absence of intercorporate dividend taxation magnifies both of these genres of agency problems while simultaneously clearing ground for a third new genre. These effects occur because, in the absence of intercorporate dividend taxation, corporations can arrange their ownership into pyramidal corporate groups. It is these pyramidal group structures that create scope for broader and deeper corporate governance problems.

The US corporate finance literature considers two distinguishable, though related agency problems that lead to corporate governance problems.

The first, initially modeled by Jensen and Meckling (1976), occurs in widely held firms - that is, firms owned by a large number of small shareholders. The top executive of such a firm makes economically inefficient decisions because she runs the firm so as to maximize her utility, rather firm value, as microeconomic theory requires. This is rational for her because she has little of her own wealth invested in the firm she runs. A standard collective action problem prevents any shareholder from spending resources on monitoring and control to prevent this. Such an agency problem will be referred to as an "other people's money" problem.

The second genre of agency problem, initially modeled by Stulz (1988), occurs in narrowly held firms - that is, firms whose top executive owns a large block of stock. This equity block gives this executive continued control even if she becomes senile, or is no longer the most able person to run the firm because technology or conditions change. The controlling shareholder/manager retains control because she obtains private benefits of control for which a more able controlling shareholder/manager could not compensate her. Poor corporate governance is thus 'locked in' by a dominant equity block. For brevity, this second genre of agency problem will be called a "management entrenchment" problem.

Morck et al. (1988) and others present empirical evidence consistent with one or the other of 
these genres of agency problem being statistically and economically important corporate governance problems in many large US firms. ${ }^{10}$

Morck et al. (2000) and Bebchuk et al. (2000) argue that pyramidal corporate groups create scope for agency problems similar to these, and for new sorts of agency problems.

To see how “other people’s money” problems can arise in pyramidal groups, recall Figure 1. In the absence of any taxes on intercorporate dividends, the family gets $51 \%$ of the dividends firm $\mathrm{A}$ disburses, with the remaining $49 \%$ going to public shareholders. But the family only gets $0.51 \mathrm{x}$ $0.51=26.01 \%$ of those paid by B, as $49 \%$ go to public shareholders directly, and $49 \%$ of the $51 \%$ paid to firm A also ultimately go to public shareholders. At successively lower levels of the pyramid, the fraction of dividends accruing to the controlling family falls geometrically.

If firm F pays a $\$ 100$ dividend, only $0.51^{6} \times \$ 100=\$ 1.76$ ends up with the controlling family. The remaining $\$ 98.84$ accrues, directly or indirectly, to public shareholders. Thus, firm F, like a widely held firm in the United States, is subject to “other people's money" agency problems of the sort described by Jensen and Meckling (1976). The controlling shareholder only bears $1.76 \%$ of the cost of poor wasted corporate resources. The situation is exactly as in a widely held firm where the senior managers own only $1.76 \%$ of the stock.

Despite this, firm $\mathrm{F}$ is fully controlled by the family. This is because the family controls $51 \%$ of the votes in each of the firms above firm $\mathrm{F}$ in the chain connecting it to the family firm. Thus, the family's control over all the firms in the pyramidal group is "entrenched" in the sense of Stulz (1988). The family cannot be dislodged via proxy fights, hostile takeovers, or other mechanisms that oust inferior managers in free-standing widely held firms.

\footnotetext{
10. Although Himmelberg, Hubbard, and Palia (1999) question the interpretation of this finding, the event study results of Fields and Mais (1994) are consistent only with agency problem explanations of the Morck et al. (1988) result.
} 
In an economy of free standing firms, like the United States, “other people's money" agency problems occur only in widely held firms, while "entrenchment" problems occur primarily in narrowly held firms. However, in a country whose firms are organized into pyramids, both problems can occur concurrently in firms low in the pyramid structure, while all the firms in the pyramid are vulnerable to "entrenchment" problems. This suggests that agency problems in economies whose firms are organized into pyramidal groups might be more severe than in economies of freestanding firms.

\section{Income Shifting, Corporate Governance and Tax Avoidance}

Finally, and perhaps most important, pyramid groups create scope for a third genre of agency problem. This is because the group firms can transfer income and assets between themselves in much the way the subsidiaries of a multinational firm do. Alworth (1989) and Gresik (2001) summarize the abundance of evidence showing that transnational corporations conduct transactions where one subsidiary provides goods, services, or capital to another at artificial prices that inflate the income of one subsidiary and reduce that of the other. The objective of these transactions is the shifting of income out of high tax jurisdictions and into low tax jurisdictions.

Bebchuk et al. (2000), Morck et al. (2000), Johnson et al. (2000) and others describe how groups of related companies such as the member firms of pyramidal corporate groups can undertake analogous non-arm's length transactions. The objective can be either avoiding taxes or transferring income and assets out of firms whose profits must be shared with public investors and into firms whose profits accrue primarily to the controlling shareholder - usually a wealthy family. Johnson et al. (2000) christen income and asset shifting of this sort 'tunneling'.

Faccio and Lang (2001), Claessens et al. (2000), Claessens et al. (2002), Bertrand et al. 
(2002), and others, in studies of East Asian and European pyramidal groups, report abnormally lower incomes and dividends in group firms situated nearer the base of the pyramid in Figure 1. This is consistent with the view that income is shifted away from firms near the base and towards firms near the apex of the pyramid. The latter are the firms that are most directly related to the wealth of the controlling family.

Of course, income shifting can also be used to avoid taxes. Harris et al. (1993) and many others present empirical evidence that such analogous shifting occurs among the subsidiaries of multinational firms in ways consistent with tax avoidance. The Congress and Administration responsible for the 1930 s extension of double taxation to intercorporate dividends also believed that such income shifting was a serious tax avoidance problem in the United States.

When tax avoidance and appropriation of public shareholders' wealth interact, simply tunneling income upward in the pyramid may no longer be the controlling shareholders preferred strategy. Note, however, that the goal of tunneling in this context is to maximize the utility of the dominant shareholder.

Critically, Johnson et al. (2000) note that such income shifting is not illegal in many countries if the objective is merely to hide income or assets from public investors. While such transactions might be objectionable to US investors, La Porta et al. (2000) show that they are unremarkable, and perfectly legal, in many countries.

\section{Political Economy and Pyramids}

Pyramidal corporate groups allow wealthy individuals or families to control corporate assets worth vastly more than their actual wealth. These groups are thus mechanisms that facilitate the concentration of corporate control in the hands of a small elite in many developing countries and in 
continental Europe.

To see how this comes about, return to Figure 1. Suppose each firm in the pyramid consists of real assets worth \$1billion plus financial assets consisting of 51\% the stock in two firms in the next lower level, down to firms in level F, which each contain only $\$ 1$ billion in real assets each. The firms in level $\mathrm{E}$ are each worth $\$ 1$ billion plus $2 \times 0.51 \times \$ 1$ billion, or $\$ 2.02$ billion each. Those in level $\mathrm{D}$ are each worth $\$ 1$ billion plus $2 \times 0.51 \times \$ 2.02$ billion, or $\$ 3.06$ billion each. Those in levels $\mathrm{C}, \mathrm{B}$, and $\mathrm{A}$ are similarly worth $\$ 4.12$ billion, $\$ 5.20$ billion and $\$ 6.31$ billion, respectively. The total value of the real assets contained in all the firms in the group is $\$ 1$ billion times the number of firms. Level A contains two firms, level B contains four, level $\mathrm{C}$ contains 8 , and so on down to level F, which contains 64 firms. The number of firms is thus $2+4+8+16+32+64=126$, and the total value of the corporate group is thus $\$ 126$ billion. However, the family firm need only hold $51 \%$ of each of the firms in level $\mathrm{A}$, or $2 \times 0.51 \times \$ 6.31$ billion $=\$ 6.43$ billion worth of stock in those firms, to control the $\$ 126$ corporate group.

The family thus leverages $\$ 6.43$ billion of actual wealth into control over $\$ 126$ billion in real corporate assets. If the family firm also contains real assets, the family's wealth requirement is greater. If the family allows a minority participation in the family firm, its wealth requirement is lower. If dual class shares, golden shares, or the like are used, the family's actual wealth can be much smaller.

Of course, the fact that pyramidal groups allow highly concentrated control over a country’s corporate section does not necessarily mean that they are social welfare destroying. Khanna and Palepu (1997) point out that managerial talent and reputations for honesty may be scarce commodities, and that pyramidal corporate groups allow families possessing these attributes to apply them to the management more assets than would be the case if they had to own firms outright to 
control them. They argue that such a scarcity is most pronounced in developing countries.

Khanna and Palepu (1997) and Khanna (2002) also propose that pyramidal business groups are substitutes for nonexistent or poorly functioning markets for goods, services, capital, and even labor in countries with poor market institutions. Non-arm's-length dealings between different firms in a pyramidal group are essential for this circumvention of dysfunctional markets. Thus, in an economy with weak institutional support for markets, business groups may be desirable as an optimal 'second best' approach to organizing economic activity in the sense of Coase (1937) and Williamson (1973).

Hoshi et al. $(1990,1991)$ argue that such considerations continue to be a factor in Japan, and that keiretsu corporate groups there provide financing for their member firms more efficiently than would capital markets or unrelated financial institutions. However, Morck and Nakamura (1999) present evidence that agency problems of the sort described above have come to characterize keiretsu, and that this ownership structure is probably now an undesirable feature of Japanese corporate finance. As noted above, there are many reasons for expecting pyramidal groups (and other cross-holding arrangements such as keiretsu) to suffer such corporate governance problems, and a growing body of evidence supports this view. It is also unclear how the tunneling detected by Johnson et al. (2000), Faccio and Lang (2001), Claessens et al. (2000), Claessens et al. (2002), Bertrand et al. (2002), and others might be construed as social welfare enhancing.

In addition, Nenova (2002) and Dyck and Zingales (2002) present evidence consistent with the view that dominant shareholders extract large private benefits of control in many economies especially those prone to extensive corruption problems, as measured by La Porta et al. (1996). Nenova (2002) shows that voting stock trades at higher prices relative to non-voting stock in more corrupt economies. Dyck and Zingales (2002) show that control blocks trade privately at prices 
more in excess of the public market price in countries with weaker institutions. Both studies can be explained if controlling shareholders can extract benefits from firms that public shareholders cannot, and can do so more readily in economies with weaker institutions. Most a propos, Dyck and Zinglaes (2002) show that the measure of corruption most highly correlated with their estimate of the magnitude of private benefits of control is slipshod enforcement of tax laws. Since more vigorous enforcement of tax laws per se renders tunneling more difficult, this finding is consistent with tunneling serving as a chief mechanism for the extraction of private benefits by the controlling shareholder.

Dyck and Zinglaes (2002) further show that countries in which private benefits of control are higher have less developed financial sectors - especially stock markets. Since King and Levine (1993) and others show that financial sector development is highly correlated with economic growth, Dyck and Zingales argue that high private benefits of control are a social welfare problem, and hence undesirable. The association between private benefits of control and tunneling implied by their tax enforcement variable suggests, following the same line of reasoning, that pyramidal corporate groups constitute a social welfare problem in countries with lax tax enforcement.

In a widely accepted model of economic growth called creative destruction, Schumpeter (1912) argues that the rise of innovative firms destroys stagnant firms. Morck and Yeung (2002) argue that very large pyramids that concentrate corporate control in the hands of a few individuals also retard growth by undermining the process of Schumpeterian creative destruction. This occurs if the same shareholder controls both firms, and internalizes the cost the innovative firm inflicts upon the stagnant firm when calculating the return to innovation. Consistent with this, Morck et al. (2000) find significantly lower private sector investment in innovation in countries with more concentrated wealth. 
A second key determinant of economic growth is the importance of political rent-seeking. Krueger (1974) and others argue that economic growth is inhibited by extensive government intervention in the economy. This is because lobbying for government favors can easily become more profitable than investment in productivity enhancement in such economies. The result is an increasing flood of capital invested in political connections (corruption) and a dearth of capital in research and development, capital spending, etc. Morck and Yeung (2003) argue that the highly concentrated corporate control pyramids allow facilitates political rent seeking by limiting the number of actors in the bargaining game between politicians and firms.

\section{The Current Discussion Regarding Dividend Taxation}

A large literature in corporate finance and public economies debates the extent to which the U.S. double taxation of dividend income affects share values and distorts savings and investment decisions. In general, the critical issue in this literature is the overall actual level of taxes on dividend income, and eliminating double taxation is important only insofar as it lowers that level. A full review is beyond the scope of this study.

One set of arguments hinges on double dividend taxation raising the actual tax level on dividends and hence depressing share prices, thereby making equity capital unduly expensive and retarding corporate investment. For a discussion of issues regarding the theoretical validity of this view, see Auerbach and Hassett (2002).

Another set of arguments, deriving from Easterbrook (1984) argues that firms prove the high quality of their governance to shareholders by paying large and growing dividends. Again, double taxation deters firms from paying such dividends, making it harder for investors to distinguish wellgoverned firms from poorly governed ones. 
The critical insight, as regards both sets of arguments, is that the current intercorporate dividend double taxation regime can generate no revenue from free-standing firms - the sorts of companies of which the US corporate sector is currently composed. This is because freestanding firms pay no intercorporate dividends. This is the whole point, for the purpose of the tax is to prevent pyramidal corporate groups by placing a heavier tax burden on them than on other companies, not to raise money. Thus, intercorporate dividend taxes sufficient to prevent pyramiding can have no effect on corporate valuation, investment policy, or payout policy of existing or new firms.

This reasoning implies that the double, or multiple taxation of intercorporate dividends be viewed in an entirely different light from double taxation of dividends paid by companies to individual shareholders. Nonetheless, the current proposals for ending the double taxation of dividend income in the United States fail to make this distinction.

The statement outlining the Bush administrations plans to end double taxation, as circulated by the Treasury Department in 2003, reads

Under the proposal, an excludable dividend received by a U.S. corporation will not be taxable. Excludable dividends received by a corporation will increase the recipient corporation's EDA (excludable dividend amount) and will, therefore, remain excludable when distributed by the recipient corporation.

\section{Blue Book, p. 20. ${ }^{11}$}

That is, from now on in the United States, Company E in Figure 1can claim dividend income received from Company $\mathrm{F}$ as "excludable dividend income", on which Company $\mathrm{E}$ need pay no corporate income tax. In turn, Company E can forward the dividend income to Company D without D

11 United States Department of the Treasury, General Explanations of the Administration's Fiscal Year 2004 Revenue Proposals (The 2003 Blue Book) is available on-line at http://www.ustreas.gov/offices/tax-policy/library/bluebk03.pdf. 
incurring any tax liability, and so on, all the way up to the apex firm of the pyramid.

Under the current US tax rules, pyramids like that in Figure 1 are prohibitively expensive because of double intercorporate dividend taxation. Under the Treasury Department's proposed changes, the pyramidal structure in Figure 1 would appear to entail no additional taxes at all. This section of the Tax Reform Proposal would seem to indicate that the Bush administration plans to end all intercorporate dividend taxation. However, the administration's position is rendered ambiguous in the next paragraph.

Returning to Table 1, current US law taxes dividends received at a statutory rate of $35 \%$. For intercorporate dividends, such as those paid by the firms in Figure 1, this rate is reduced to 7\%. This reduction is accomplished by allowing the recipient corporation a "dividends received deduction" equal to $80 \%$ of the dividends it receives in cases where the recipient firm owns between twenty and eighty percent of the dividend paying firm. As Table 1 shows, only if the recipient's stake exceeds eighty percent is a one hundred percent deduction allowed. The administration's reform proposal explains that

Under current law, a corporation that receives a dividend from another corporation is entitled to a dividends received deduction. Under the proposal, the 100 percent deduction for dividends received from a corporation 80 percent or more of which is owned by another corporation will be retained. The 70 and 80 percent deductions for dividends received, however, will only be available for distributions of pre-2001 earnings and profits that are distributed before January 1, 2006, with respect to stock issued before February 3, 2003.

2003 Blue Book p. 20.

One reading of this paragraph is that the partial "dividends received deductions" will be eliminated because the EDA rules allow the equivalent of a one hundred percent deduction in all cases. Another is that the EDA will only be available to the recipient if its stake in the dividendpaying firm exceeds eighty percent. The elimination of the partial deductions might then be read as 
implying full double taxation of intercorporate dividends in all other cases.

Resolution of this ambiguity may lie in a different paragraph outlining the overall objective of the reforms as regards intercorporate dividend taxation. The Treasury Department seems aware that these changes will allow pyramidal corporate groups in the United States, for the proposal states

These additions to EDA will ensure that multiple levels of corporate ownership do not result in more than one level of tax on income that has been previously taxed at the corporate level.

2003 Blue Book, p. 14.

Although this phrasing does not explicitly address the ambiguity of the proposal in its current form, an interpretation consistent with this philosophy favors the view that all intercorporate dividends are to be exempted from double taxation.12 This would align US taxation of intercorporate dividends with that of other countries, such as Canada's regime described in Table 1, and would remove the current tax penalty on pyramidal groups.

If intercorporate dividend taxes are the primary reason pyramidal groups do not exist in the United States, this change opens the door to their establishment in that country. If such groups do not form despite the absence of tax disincentives, economists will have an interesting puzzle to analyze. Work on other countries suggests that the formation of pyramidal groups in the United States would probably have deleterious effects on US corporate governance, corporate tax compliance, and on the concentration of corporate control, though these effects are not certain.

\section{Conclusions}

12 A private communication with Glen Hubbard, Chairman of the Council of Economic Advisors to President George W. Bush while the tax reform plans were drawn up confirms this interpretation. 
This paper neither promotes nor criticizes any particular policy agenda. Its purpose is to emphasize that the economic arguments surrounding the double or multiple taxation of intercorporate dividends differ starkly from those surrounding the double taxation of dividends paid to individuals, and that the current US dividend tax reform proposals do not make this distinction.

In the 1930s, the Congress and President that originally extended double (and multiple) taxation to intercorporate dividends believed that pyramidal groups wrought problems of corporate governance, tax avoidance, and concentrated corporate control. The current discussion about eliminating the double taxation of dividend income should be informed by a historical understanding of why the double (and multiple) taxation of intercorporate dividends was initiated.

Pyramidal corporate groups exist in virtually all countries that do not tax intercorporate dividends. Empirical research on the financial systems of such countries indicates that these groups create scope for the abuse of public shareholders. The US experience prior to the 1930 s reforms and empirical work on multinational firms with similar structures to those of pyramidal groups suggests that pyramidal groups offer considerable potential for corporate tax avoidance. And pyramidal corporate groups allow an extreme concentration of economic power. These are the structures that allow tiny elites to control the greater parts of the corporate sectors of many Latin American, Asian, and European countries.

It is not clear that abolishing the double (and multiple) taxation of intercorporate dividends would lead to such outcomes in the United States. Vigorous actions by the Internal Revenue Service to prevent transfer pricing and income shifting in related-party intercorporate transactions might prevent effective tunneling. Shareholder activism in the United States could also prevent controlling shareholders in corporate groups from extracting private benefits of control. And the depth of democracy in the US might mitigate problems associated with excessive concentration of corporate 
control in the hands of a small elite.

Moreover, other restrictions on pyramiding remain. For example, the Public Utilities Holding Company Act (PUHCA) of 1935 restricts large pyramidal groups holdings of public utilities such as power or water companies. Starting in 1920, the number of electric power firms declined dramatically because of pyramiding. ${ }^{13}$ Utilities throughout the country came under the control of a small number of holding companies, which themselves were owned by other holding companies. As many as ten layers separated the top and bottom of some pyramids. By 1932, three groups controlled $45 \%$ of the electricity generated in the United States. Responding to evidence of tunneling, poor governance, monopolistic pricing, and the failure of many highly levered pyramids subsequent to 1929, Congress enacted PUHCA, subjecting utilities to federal regulation and banning pyramids more than two layers high in that industry. ${ }^{14}$

Nonetheless, the strength of these other factors vis à vis intercorporate dividend taxation is unknown. Utility companies are important elements of some pyramidal groups in other countries, but pyramids can certainly exist without encompassing utilities. Moreover, most public utilities in the US are now exempt from PUHCA because they operate within a single state. Vigorous tax enforcement, corporate governance activism, and grassroots democracy might also prevent pyramiding, or limit its impact. But this is far from certain. The full consequences of abolishing double and multiple intercorporate dividend taxation in the United States are ill understood at best.

While substantive economic arguments support the abolition of double taxation on dividends paid to individual investors, there is no compelling reason to end the double taxation of intercorporate dividends. Nonetheless, the current US proposal for eliminating double taxation does

\footnotetext{
13 Abel (1999).
} 
not distinguish double taxation of intercorporate dividends from double dividend taxation in general.

Abolishing the double (and multiple) taxation of intercorporate dividends could have sweeping consequences for corporate governance, corporate taxation, and corporate control. If the Treasury Department intends to permit pyramidal corporate groups in the United States, research on the desirability of this reform should be an urgent priority. If pyramidal groups are deemed undesirable, more nuanced tax reforms can readily be envisioned that continue subjecting intercorporate dividends to double and multiple taxation while eliminating the double taxation of dividends paid by free-standing corporations to individuals.

14 Title I $§ 11 b$ (the "Death Sentence Clause") forbids holding companies more than twice removed from an operating subsidiary. Deregulation of the power industry in the 1990s left the pyramiding 


\section{References}

Abel, Amy. 1999. Electricity Restructuring Background: Public Utility Holding Company Act of 1935 (PUHCA). Congressional Research Service, Environment and Natural Resources Policy Division, Library of Congress, Report for Congress RS20015 (January 7, 1999).

Aganin, Alexander and Paolo Volpin. 1998. On the Origin and Evolution of Pyramidal Groups: An Empirical Evaluation. Harvard University working paper.

Auerbach, Alan and Kevin Hassett. 2002. On the marginal source of investment funds. Journal of Public Economics 87 205-232

Bali, Rakesh and Gailen L. Hite. 1998. Ex-Dividend Day Stock Price Behavior: Discreteness or Tax-Induced Clienteles? Journal of Financial Economics 47 127-159.

Barclay, Michael. 1987. Dividends, Taxes, and Common Stock Prices: The Ex-Dividend Day Behavior of Common Stock Prices Before the Income Tax. Journal of Financial Economics $1931-43$.

Bebchuk, Lucien, Reinier Kraakman, and George Triantis. 2000. Stock Pyramids, Cross Ownership and Dual Class equity: The Mechanisms Aand Agency Costs of Separating Control from Cash Flow Rights. In R. Morck ed. Concentrated Corporate Ownership. National Bureau of Economic Research Conference Volume. University of Chicago Press.

Bernheim, B. Douglas. 1991. Tax Policy and the Dividend Puzzle. RAND Journal of Economics 22 455-476.

Bernheim, B Douglas and Adam Wantz. 1995. A tax-based test of the dividend signaling hypothesis. American Economic Review 85(3) 532-52.

Bertrand, Marianne, Paras Mehta, and Sendhil Mullainathan. 2002. Ferreting out tunneling: An application to Indian business groups. Quarterly Journal of Economics 117(1) 121-148. 
Black, Fischer, and Myron Scholes. 1974. The Effects of Dividend Yield and Dividend Policy on Common Stock Prices and Returns. Journal of Financial Economics 1 1-22.

Blakey, Roy and Gladys Blakey. 1935. The Revenue Act of 1935. American Economic Review 25(4) 673-690.

Blakey, Roy and Gladys Blakey. 1936. The Revenue Act of 1936. American Economic Review26(3) 466-482.

Bradford, David. 1981. The Incidence and Allocation Effects of a Tax on Corporate Distributions. Journal of Public Economics 15 1-22.

Brittain, John. 1964. The Tax Structure and Corporate Dividend Policy. American Economic Review 54(3) 272-287.

Chen, Nai-Fu, Bruce Grundy, and Robert F. Stambaugh. 1990. Changing Risk, Changing Risk Premiums and the Dividend Yield Effect. Journal of Business 63 178-206.

Claessens Stijn, Simeon Djankov, Larry H.P. Lang. 2000. The separation of ownership and control in East Asian Corporations, Journal of Financial Economics (58)1-2 81-112.

Claessens, Stjin, Simeon Djankov, Joseph Fan, and Larry Lang. 2002. Expropriation of minority shareholders in East Asia. Journal of Finance, forthcoming.

Coase, Ronald. 1937. The Nature of the Firm. Economica Nov. 386-405.

Collins, Julie, and Deen Kemsley. 1998. Capital Gains Taxation in Firm Valuation and Dividend Policy. University of North Carolina working paper.

Collins, Julie H. and Deen Kemsley. 2000. Capital gains and dividend taxes in firm valuation: Evidence of triple taxation. Accounting Review 75(4) 405-427.

Daniels, Ron, Randall Morck and David Stangeland. 1995. High Gear: A Case Study of the HeesEdper Corporate Group. In R. Daniels and R. Morck, eds. Corporate Decision Making in 
Canada. Industry Canada and the University of Calgary Press. Calgary.

Dyck, Alexander and Luigi Zingales. 2001. Why Are Private Benefits of Control so Large in Certain Countries and What Effects Does This Have on Their Financial Development? Unpublished manuscript.

Eades, Kenneth M., Patrick J. Hess, and E. Han Kim. 1984. On Interpreting Security Returns During the Ex-Dividend Period. Journal of Financial Economics 13 3-34.

Easterbrook, Frank. 1984. Two Agency-Cost Explanations of Dividends. American Economic Review 78 650-659.

Elton, Edward, and Martin Gruber. 1970. Marginal Stockholder Tax Rates and the Clientele Effect. Review of Economics and Statistics 52 68-74.

Faccio, Mara and Larry Lang. 2001. The Separation of Ownership and Control: An Analysis of Ultimate Ownership in Western European Countries. Working paper.

Faccio, Mara, Larry Lang and Leslie Young. 2001. Dividends and expropriation. American Economic Review 91(1) 54-78.

Fama, Eugene F., and Kenneth R. French. 1998. Taxes, Financing Decisions, and Firm Value. Journal of Finance 53 819-843.

Fama, Eugene F., and Kenneth R. French. 1998. Dividend Yields and Expected Stock Returns. Journal of Financial Economics 22(1) 3-26.

Feenberg, Daniel. 1981. Does the investment interest limitation explain the existence of dividends? Journal of Financial Economics 9(3) 265-269.

Feldstein, Martin. 1970. Corporate Taxation and Dividend Behavior. Review of Economic Studies 37 $57-72$.

Fields, L Paige, and Eric Mais. 1994. Managerial voting rights and seasoned public equity issues. 
Journal of Financial and Quantitative Analysis 29(3) 445-58.

Gentry, William, and R. Glenn Hubbard. 1998. Fundamental Tax Reform and Corporate Financial Policy. In James Poterba, ed., Tax Policy and the Economy, vol. 12. Cambridge: MIT Press.

Gordon, Roger and David Bradford. 1980. Taxation and the Stock Market Valuation of Capital Gains and Dividends: Theory and Empirical Results. Journal of Public Economics 14 109136.

Gresik, Thomas A. 2001. The taxing task of taxing transnationals. Journal of Economic Literature 39(3) 800-838.

Harris, Trevor, R Glenn Hubbard, and Deen Kemsley. 1999. The share price effects of dividend taxes and tax imputation credits. Journal of Public Economics 79(3) 569-596.

Harris, Trevor S., and Deen Kemsley. 1999. Dividend Taxation in Firm Valuation: New Evidence. Journal of Accounting Research 37 275-292.

Harris, David, Randall Morck, Joel Slemrod and Bernard Yeung. 1993. Income Shifting in U.S. Multinational Corporations. In J. Slemrod et al., eds. International Aspects of Taxation, National Bureau of Economic Research Conference Volume, University of Chicago Press.

Himmelberg, Charles, R. Glenn Hubbard, and Darius Palia. 1999. Understanding Determinants of Managerial Ownership and the Link Between Ownership and Performance. Journal of Financial Economics 37

Holderness, Clifford, Randall Kroszner, and Dennis Sheehan. 1999. Were the Good Old Days That Good?: Changes in Managerial Stock Ownership Since the Great Depression. Journal of Finance 54(1).

Hoshi, Takeo, Anil Kashyap and David Scharfstein. 1990. The role of banks in reducing the costs of financial distress in Japan. Journal of Financial Economics, 27, 67-88. 
Jensen, Michael and William Meckling 1976. The Theory of the Firm: Managerial Behavior, Agency Costs and Ownership Structure. Journal of Financial Economics. 3 305-360.

Jensen, Michael. 1986. Agency Costs of Free Cash Flow, Corporate Finance, and Takeovers. American Economic Review 76 323-329.

Johnson, Simon, Rafael La Porta, Florencio Lopez-de-Silanes, and Andrei Shleifer. 2000. Tunneling. American Economic Review 90(2) May 22-27.

Kalay, Avner. 1982. The Ex-Dividend Day Behavior of Stock Prices: A Reexamination of the Clientele Effect. Journal of Finance 37 1059-1070.

Khanna, T., and Palepu, K. 1997. Why Focused Strategies May be Wrong for Emerging Markets. Harvard Business Review, July-August.

Khanna, Tarun. 2002. Business Groups and Social Welfare in Emerging Markets: Existing Evidence and Unanswered Questions. European Economic Review forthcoming.

King, Mervyn.1977. Public Policy and the Corporation. Chapman and Hall, London.

King, Robert G. and Ross Levine, 1993. Finance and Growth: Schumpeter Might Be Right. Quarterly Journal of Economics 108:3, 717-737.

King, Mervyn. 1977. Public Policy and the Corporation. London: Chapman and Hall.

Krueger, Anne. 1974. The Political Economy of the Rent-Seeking Society. American Economic Review 64 June 291-303.

Lamdin, Douglas J., and Craig Hiemstra. 1993. Ex-Dividend-Day Share Price Behavior: Effects of the Tax Reform Act of 1986." Review of Economics and Statistics 75 778-783.

La Porta, Rafael, Florencio Lopez-de-Salines, and Andrei Shleifer. 1999. Corporate Ownership Around the World. Journal of Finance 54(2) 471-517.

La Porta, Rafael, Florencio Lopez-de-Salines, and Andrei Shleifer. 2000. Investor Protection and 
Corporate Governance. Jounral of Financial Economics 59 (1-2) 3-27.

Lasfer, M. Ameziane. 1995. Ex-Day Behavior: Tax or Short-Term Trading Effects. Journal of Finance 50 875-897.

Litzenberger, Robert and Krishna Ramaswamy. 1979. The Effect of Personal Taxes and Dividends on Capital Asset Prices: Theory and Empirical Evidence. Journal of Financial Economics 7 163-195.

Litzenberger, Robert and Krishna Ramaswamy. 1982. The Effects of Dividends on Common Stock Prices: Tax Effects or Information Effects? Journal of Finance 37 429-443.

Miller, Merton and Myron Scholes. 1982. Dividends and Taxes: Some Empirical Evidence. Journal of Political Economy 90(6) 1118-42.

Miller, Merton and Myron Scholes. 1978. Dividends and Taxes. Journal of Financial Economics 6(4) $333-53$.

Morck, Randall, Andrei Shleifer and Robert Vishny. 1988. Management Ownership and Market Valuation: An Empirical Analysis. Journal of Financial Economics, Vol. 20, No. 1/2, Jan./Mar. 293-315.

Morck, Randall and Masao Nakamura. 1999. Banks and corporate control in Japan. Journal of Finance. Feb. 54(1) 319-340.

Morck, Randall, David A. Stangeland, and Bernard Yeung. 2000. Inherited Wealth, Corporate Control, and Economic Growth: The Canadian Disease. In R. Morck ed. Concentrated Corporate Ownership. National Bureau of Economic Research Conference Volume. University of Chicago Press.

Morck, Randall and Bernard Yeung. 2003. Family Control and the Rent-Seeking Society. New York University working paper. 
Morck, Randall and Yeung, Bernard. 2002. The Political Economy of the Family Firm. Entrepreneurship Theory and Practice. Forthcoming.

Nenova, Tatiana. 2000. The Value of Corporate Votes and Control Benefits: A Cross-Country Analysis. Harvard University Economics Working Paper

Phillips, Charles. 1993. The Regulation of Public Utilities, Theory and Practice. Public Utilities Reports, Inc. Arlington, VA.

Poterba, James. 1987. Tax Policy and Corporate Saving.” Brookings Papers on Economic Activity 1987(2) 455-575.

Poterba, James and Lawrence Summers. 1983. Dividend Taxes, Corporate Investment, and 'Q'. Journal of Public Economics 22(2) 135-68.

Poterba, James and Lawrence Summers. 1984. New Evidence That Taxes Affect the Valuation of Dividends. Journal of Finance 39(5) 1397-1415.

Poterba, James and Lawrence Summers. 1985. The Economic Effects of Dividend Taxation. In Edward Altman and Marti Subrahmanyan, eds. Recent Advances in Corporate Finance. Homewood: R.D. Irwin.

Roosevelt, Franklin D. 1942. Appendix A: Message from the President of the United States Transmitting Recommendations Relative to the Strengthening and Enforcement of Anti-trust Laws. American Economic Review 32(2) Supplement, Papers Relating to the Temporary National Economic Committee 119-128.

Schumpeter, Joseph A. 1912. Theorie der Wirtschaftlichen Entwichlung, Leipzig, Dunker und Humbolt. Translation by R. Opie (1934), The Theory of Economic Development: An Inquiry into Profits, Capital, Credit, Interest, and the Business Cycle. Cambridge Mass: Harvard University Press. 
Shaw, Wayne. 1991. An Examination of Ex-Dividend Day Stock Price Movements: The Case of Nontaxable Master Limited Partnership Distributions.” Journal of Finance 46 755-771.

Sinn, Hans-Werner. 1985. Capital Income Taxation and Resource Allocation. Amsterdam: North Holland.

Sinn, Hans-Werner. 1991. Taxation and the Cost of Capital: The 'Old View,' the 'New View,' and Another View. In David F. Bradford, ed. Tax Policy and the Economy, vol. 5. Cambridge: MIT Press.

Stulz, René. 1988. On Takeover Resistance, Managerial Discretion and Shareholder Wealth. Journal of Financial Economics 20(1/2) Jan./Mar. 25-54.

Summers, Lawrence. 1981. Taxation and Corporate Investment: A q-theory Approach.” Brookings Papers on Economic Activity 1981(1) 67-127.

Williamson, Oliver. 1973. Markets and hierarchies: Some Elementary Considerations. American Economic Review May 316-325.

Zodrow, George. 1991. On the 'Traditional' and 'New' Views of Dividend Taxation.” National Tax Journal 44 497-509. 
Table 1. Top Personal and Corporate Federal Tax Rates Payable on Dividend Income in the United States and Canada, as of 2002

\begin{tabular}{|c|c|c|c|c|c|c|}
\hline \multirow{3}{*}{$\begin{array}{c}\text { recipient's } \\
\text { ownership } \\
\text { of payer }\end{array}$} & \multicolumn{3}{|c|}{ United States } & \multicolumn{3}{|c|}{ Canada } \\
\hline & \multirow{2}{*}{$\begin{array}{l}\text { initial payer } \\
\text { corporation }^{a}\end{array}$} & \multicolumn{2}{|c|}{ recipient is } & \multirow{2}{*}{$\begin{array}{c}\text { initial payer } \\
\text { corporation }^{b}\end{array}$} & \multicolumn{2}{|c|}{ recipient is } \\
\hline & & individual $^{a}$ & corporation & & individual $^{b, c}$ & corporation \\
\hline $0-10 \%$ & $35 \%$ & $38.6 \%$ & $10.5 \%$ & $38.62 \%$ & $31.34 \%$ & $38.62 \%$ \\
\hline $10-20 \%$ & $35 \%$ & $38.6 \%$ & $10.5 \%$ & $38.62 \%$ & $31.34 \%$ & $0 \%$ \\
\hline $20-80 \%$ & $35 \%$ & $38.6 \%$ & $7 \%$ & $38.62 \%$ & $31.34 \%$ & $0 \%$ \\
\hline $80 \%+$ & $35 \%$ & $38.6 \%$ & $0 \%$ & $38.62 \%$ & $31.34 \%$ & $0 \%$ \\
\hline
\end{tabular}
a. Top marginal rate, federal taxes only
b. Combined federal and Ontario rates. Ontario is chosen as a representative provincial tax system. Provincial taxes are a larger fraction of the total in Canada and meaningful comparisons with other countries cannot exclude them.
c. After grossing up and dividend tax credit provisions are included. 
Table 2. Tax Rates on Intercorporate Dividend Income From Controlled Publicly Traded Firms Effective in Various Countries in 1982 and 1997 and Existence of Pyramiding

\begin{tabular}{|c|c|c|}
\hline Country & $\begin{array}{c}\text { Intercorporate dividend } \\
\text { tax rate }\end{array}$ & $\begin{array}{l}\text { Pyramidal or other group } \\
\text { members among top } 10 \text { firms }\end{array}$ \\
\hline Argentina & $0 \%$ & yes \\
\hline Australia & $0 \%$ & yes \\
\hline Austria & $0 \%$ & yes \\
\hline Belgium & $0 \%$ & yes \\
\hline Brazil & $0 \%$ & yes \\
\hline Canada & $0 \%$ & yes \\
\hline Chile & $0 \%$ & yes \\
\hline Denmark & $0 \%$ & yes \\
\hline Finland & $0 \%$ & yes \\
\hline France & $0 \%$ & yes \\
\hline Germany & $0 \%$ & yes \\
\hline Greece & $0 \%$ & yes \\
\hline Hong Kong & $0 \%$ & yes \\
\hline India* & $0 \%$ & yes \\
\hline Indonesia & $0 \%$ & yes \\
\hline Ireland & $0 \%$ & yes \\
\hline Italy & $0 \%$ & yes \\
\hline Japan & $0 \%$ & yes \\
\hline Korea** & $0 \%$ * & yes \\
\hline Malaysia & $0 \%$ & yes \\
\hline Mexico & $0 \%$ & yes \\
\hline Netherlands & $0 \%$ & yes \\
\hline New Zealand & $0 \%$ & yes \\
\hline Norway & $0 \%$ & yes \\
\hline Portugal & $0 \%$ & yes \\
\hline Singapore & $0 \%$ & yes \\
\hline Spain & $0 \%$ & yes \\
\hline Sweden & $0 \%$ & yes \\
\hline Switzerland & $0 \%$ & yes \\
\hline Thailand & $0 \%$ & yes \\
\hline United Kingdom & $0 \%$ & no \\
\hline United States & $7.0 \%$ & no \\
\hline
\end{tabular}

Sources: Tax rate information is from International Bureau of Fiscal Documentation tax code summaries, Price Waterhouse Tax Information booklets, and telephone and other discussions with accountants in various countries. Group structure information is based on data provided by Rafael La Porta, annual reports, and telephone and other discussions with bankers and finance academics from various countries.

* Intercorporate dividends are exempted for firms on special lists in India.

** Intercorporate dividends are tax exempt in Korea for officially recognized Chaebol member firms only. Other firms are subject to a $33 \%$ to $40 \%$ tax on intercorporate dividends. 
Figure 1. A Stylized Representation of a Pyramidal Corporate Group

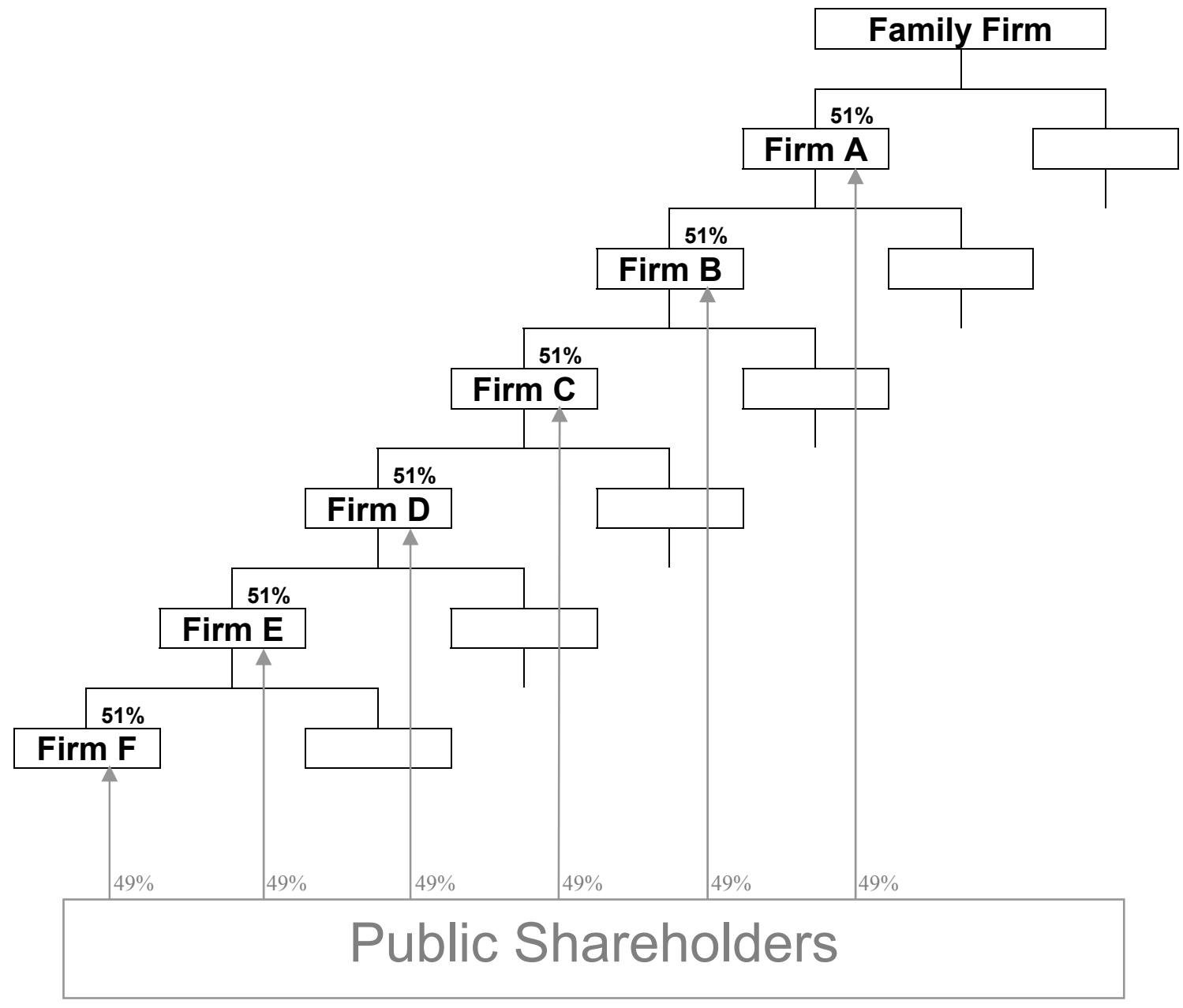



Figure 2. Typical Large Publicly Traded Corporations Outside the US: A Part of the Hees-Edper Corporate Group in Canada

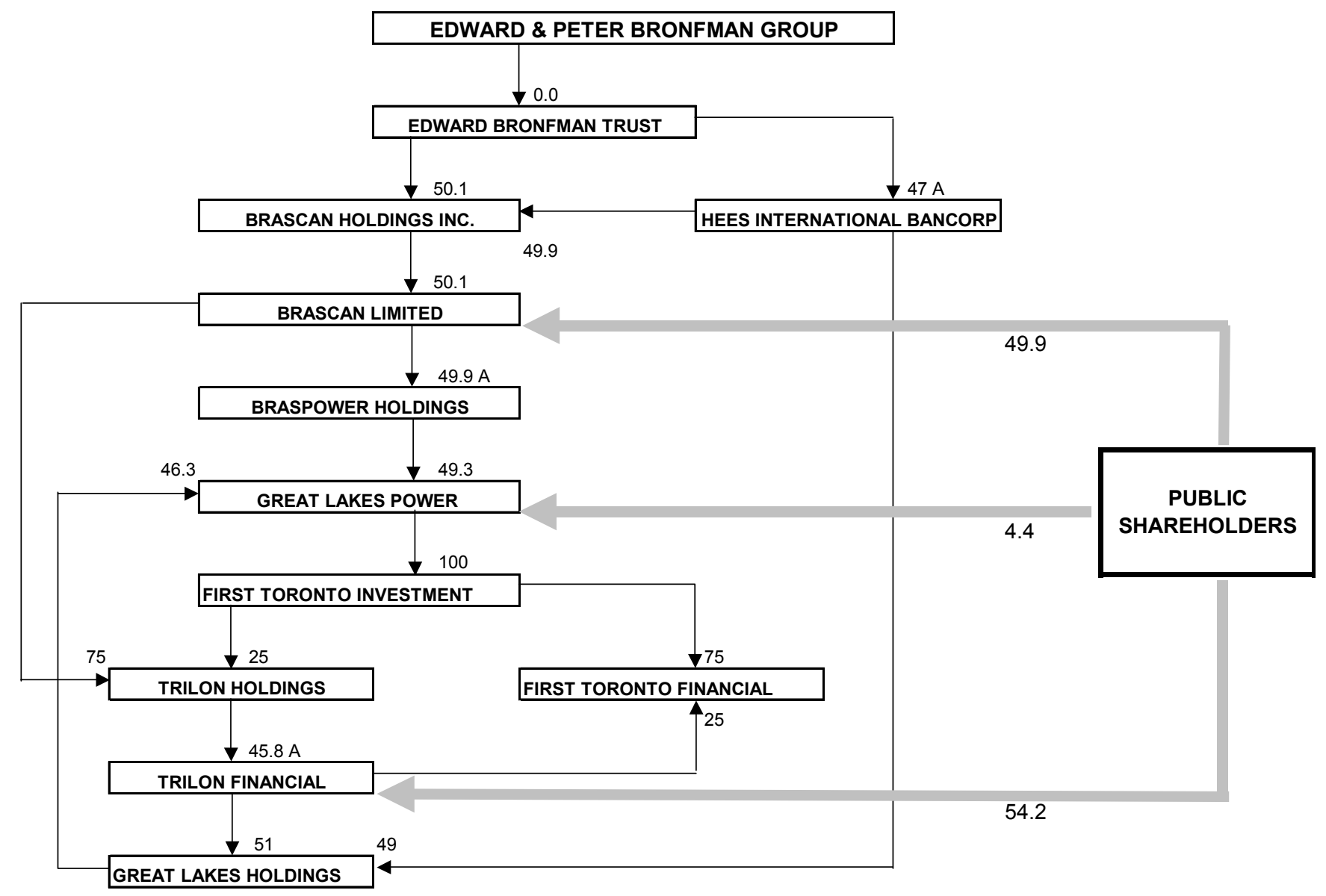

Note: Firms not controlled via majority equity blocks are controlled via director interlock, dual class shares, or other means. Source: Directory of Intercorporate Ownership, Statistics Canada, 1997. 
Figure 3. Typical Large Publicly Traded Corporations Outside the US: The Anglo-American Group in South Africa

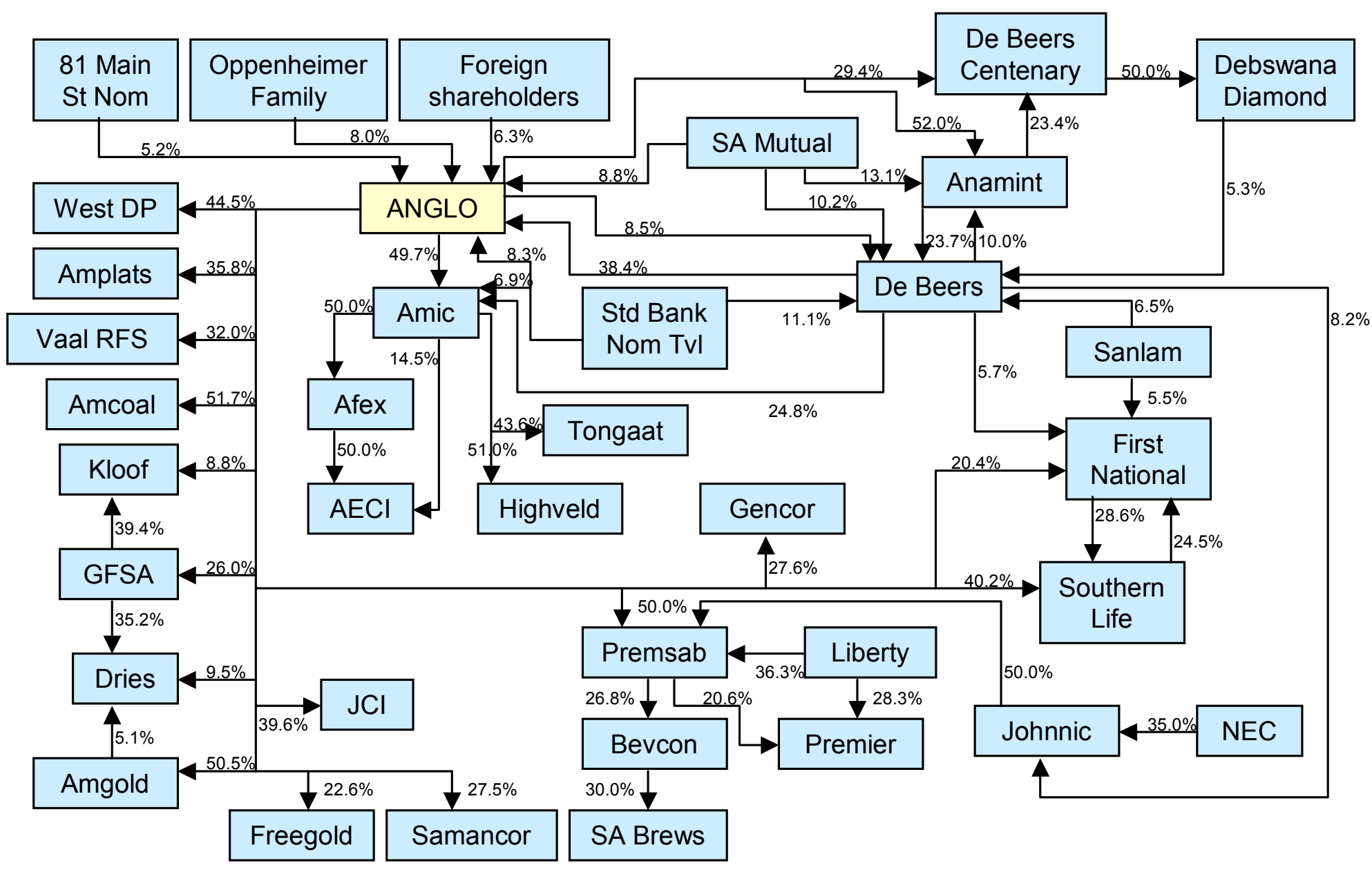

Source: Financial Mail 
Figure 4. Typical Large Publicly Traded Corporations Outside the US: Firms Controlled by the Agnelli Family in Italy

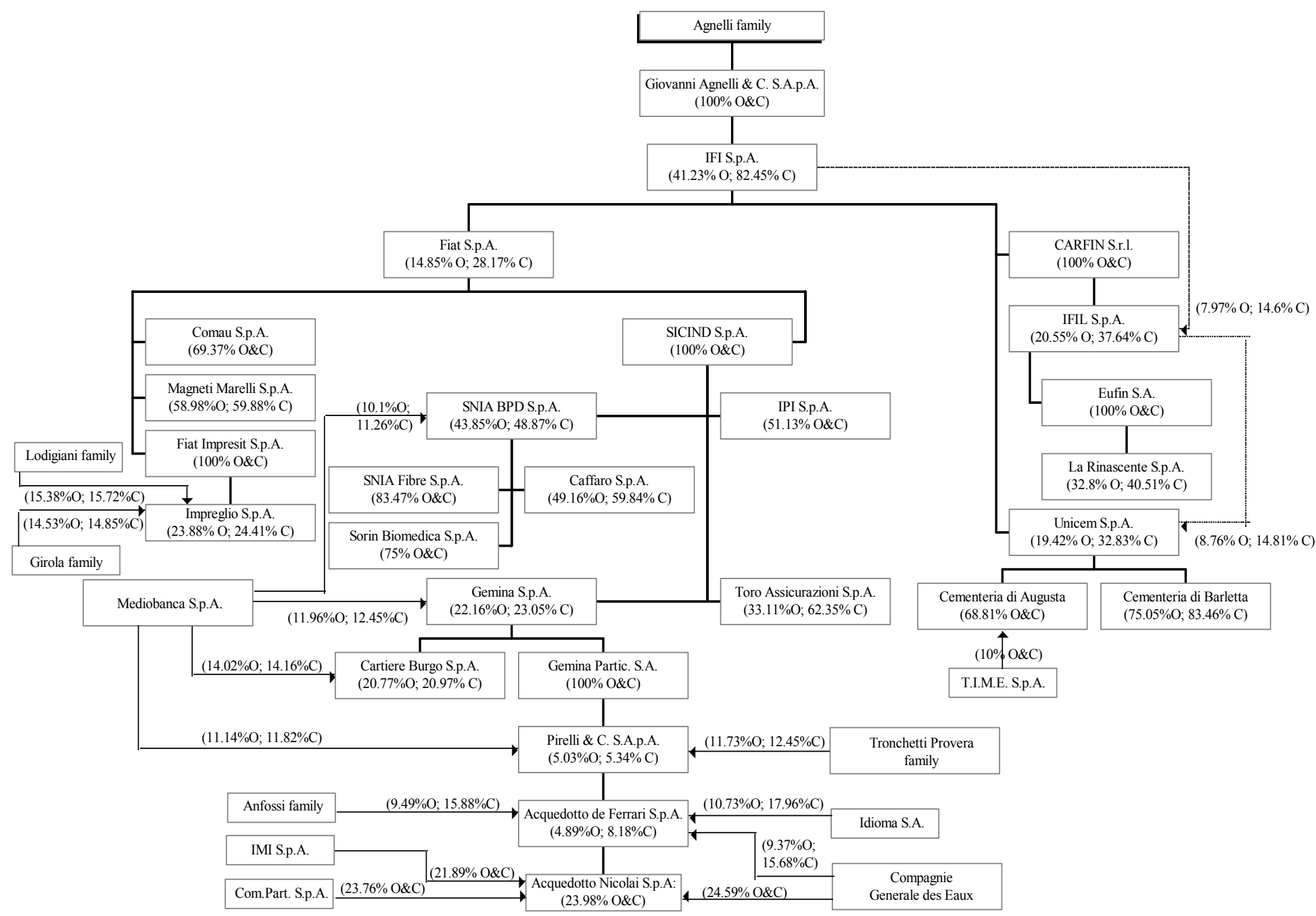

Source: Faccio and Lang (2001). 
Figure 5. Typical Large Publicly Traded Corporations Outside the US: The Deutsche Bank Group in Germany

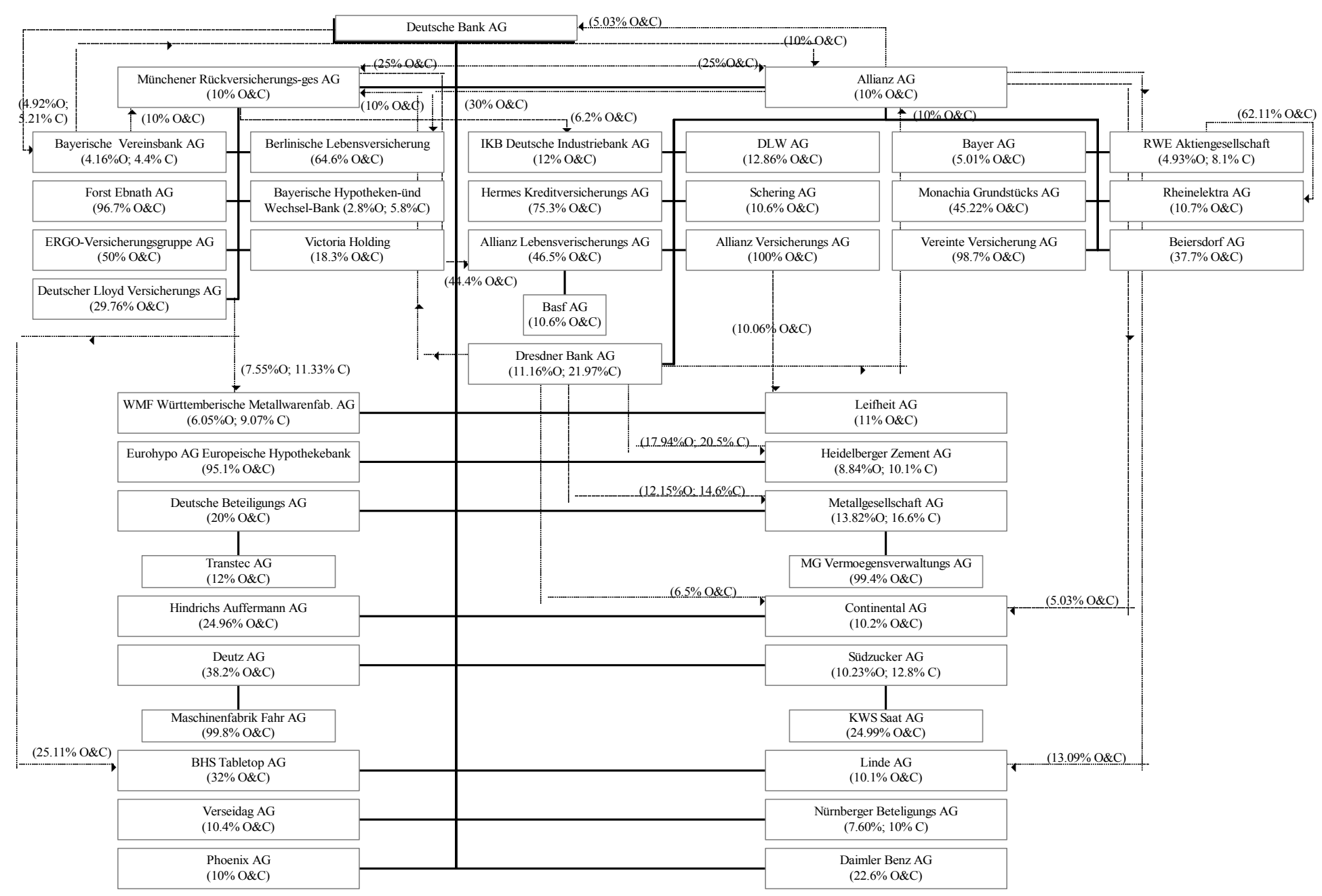

Source: Faccio and Lang (2001). 
Figure 6. Typical Large Publicly Traded Corporations in the US: 3M Corporation

\begin{tabular}{|c|c|}
\hline $\begin{array}{c}3 \text { M Corporation } \\
\text { Listed }\end{array}$ & $\begin{array}{c}\text { US subsidiaries } \\
\text { Not listed }\end{array}$ \\
&
\end{tabular}

Public shareholders

Officers, directors \& related parties

Combined stake > 99\% Combined stake $<1 \%$ 